\title{
THE MORAL DEVELOPMENT OF CHRISTIAN YOUTH
}

\author{
Ana S. Iltis*
}

Abstract: The Church has a vital role to play in supporting and supplementing parents' efforts to raise pious Orthodox Christian children. Parents bear primary responsibility for raising their children in the faith with the help of Godparents. In the $21^{\text {st }}$ Century, the Church must work more than ever to ensure that the youth are educated not only in the faith but on how to live as Christians in a secular world. Three reasons for this are examined in this paper. The first is what we know about child and adolescent psychology. Children in general, and adolescents in particular, seek the approval of their peers and can be heavily influenced by them. Helping adolescents develop an Orthodox Christian peer group can help them to resist the temptations offered by secular peers. Parents often cannot foster such peer groups alone, and the Church can make it possible for adolescents to develop strong Christian peer groups. Second, the world has become increasingly secular and hostile to Christians. Social, political, and legal pressures undermine the authority of parents to raise their children with strong Christian commitments. Third, many Orthodox Christian children are being raised by parents who themselves were brought up in less observant Christian homes or whose parents are converts. Parents who did not grow up with an example of how to raise Orthodox children, so they cannot follow the example of their parents in raising their children. They need the help of the Church not only to help raise their children in a secular world but to learn the practices and traditions of the Orthodox Church. The paper concludes with a series of specific examples about the ways in which the Church can help to support parents and in the education of Orthodox youth, especially adolescents.

Keywords: adolescents, education, secularization.

* $\mathrm{PhD}$, Professor of Philosophy, Director, Center for Bioethics, Health and Society Wake Forest University, Winston-Salem, North Carolina, USA. 


\title{
Introduction
}

In St. Paul's letter to the Ephesians, he writes:

\begin{abstract}
„And He Himself gave some to be apostles, some prophets, some evangelists, and some pastors and teachers, for the equipping of the saints for the work of ministry, for the edifying of the body of Christ, till we all come to the unity of the faith and of the knowledge of the Son of God, to a perfect man, to the measure of the stature of the fullness of Christ; that we should no longer be children, tossed to and fro and carried about with every wind of doctrine, by the trickery of men, in the cunning craftiness of deceitful plotting, but, speaking the truth in love, may grow up in all things into Him who is the head Christ - from who the whole body, joined and knit together by what every joint supplies, according to the effective working by which every part does its share, cause growth of the body for the edifying of itself in love" (Eph. 4: 11-16).
\end{abstract}

In this passage, we see that the Church as a whole and each parish has three primary tasks: "the perfecting of the saints, the work of ministry, the building up of the Body of Christ" (Pomazansky 1991). The first task, the salvation of souls, is the fundamental purpose of the Church and its most important function. It is primarily through prayer, the Divine services, and the sacraments that pastors care for the souls entrusted to them.

The third task is to build up and support the Orthodox Church as a whole. This can be accomplished in numerous ways, including fostering Orthodox unity, prayers for such unity, defending the Church, and supporting Church centers (Pomozansky 1991).

The second task is the focus of the discussion here. It is the ministry to parishioners and to others (Pomozansky 1991). Ministry work can include charitable activities to help the poor and sick and those who are alone. It can include caring for church buildings, singing in a church choir, reading, and serving in the altar. Ministry work also includes efforts to educate parishioners in the Faith and to help raise Christian children and adolescents. 
Parents bear primary responsibility for raising their children in the Faith (with the help of Godparents). In the $21^{\text {st }}$ Century, the Church must work more than ever to ensure that the youth are educated not only in the faith but on how to live as Christians in a secular world. There are three main reasons for this. The first is what we know about child and adolescent psychology. Children in general, and adolescents in particular, seek the approval of their peers and can be heavily influenced by them. Helping adolescents develop an Orthodox Christian peer group can help them to resist the temptations offered by secular peers. Parents often cannot foster such peer groups alone, and the Church can make it possible for adolescents to develop strong Christian peer groups. Second, the world has become increasingly secular and hostile to Christians. Social, political, and legal pressures undermine the authority of parents to raise their children with strong Christian commitments. Third, many Orthodox Christian children are being raised by parents who themselves were brought up in less observant Christian homes or the parents are converts. This means that many parents today did not grow up with an example of how to raise Orthodox children, so they cannot follow the example of their parents. They also may not be familiar with important traditions and practices. The Church can help children and their parents learn these traditions so that they may be preserved. I conclude with a series of specific examples about the ways in which the Church can help to support parents in the education of Orthodox youth, especially adolescents. The Church has a vital role to play in supporting and supplementing parents' efforts to raise pious Orthodox Christian children.

\section{Adolescents: Secular and Christian Peers}

Most adults, I imagine, recognize that teenagers often are highly influenced by their peers and care deeply about what their peers think. Adolescents often want to spend as much time as possible with their peers - either in real life or virtually using technology - and as little time as possible with their parents. There 
is a significant amount evidence that peer influence is an important factor in many decisions adolescents make and in how they behave (Lashbrook 2000). These include educational goals and performance (Coleman, 1961; Duncan, Haller, \& Portes, 1968; Nelson and DeBacker 2008); use of alcohol, drugs, and cigarettes (Kandel \& Andrews, 1987); and sexual behavior (Shah \& Zelnick, 1981).

An immense cultural shift in the $20^{\text {th }}$ century means that today, many children are being raised in non-traditional families. They may be raised by a single mother or a single father, they may have two mothers or two fathers, there may be step-parents involved in their lives as well as step-siblings and half-siblings, and they may have no religious foundation. In contemporary society, many adolescents likely will have many secular peers. These teens may have been raised in homes in which attitudes toward sexual activity outside of marriage, homosexual activity, and other important moral matters are decidedly anti-Christian. To counter-act the influence of such peers requires involved, Christian parents committed to raising their children in the Church. It also requires creating a Christian peer group that can help adolescents resist the secular peer group's influences. This is one place the Church can play a vital role. By encouraging teens to be part of the life of the Church, to understand and practice their faith, and by giving them opportunities to be with other Christian children their age, the Church can support parents who are trying to create the best influences possible for their children. The important role peer groups play in adolescents' lives and the fact that teens today are likely to have many secular peers with non-Christian and even anti-Christian views makes it ever more important to create Christian peer groups. I will share some specific examples of how this can be done later.

\section{Secularization: Social, Political and Legal Pressures}

A second reason parents need the support of the Church to raise pious Orthodox children is that there are many social, political, 
and legal pressures that not only can make it difficult for parents to raise their children as Christians but can undermine the authority of parents to do so. These pressures arise from many different sources and at many different levels. At the local level, they might include secular sexual education in schools that teaches children that sex outside of marriage and sexual experimentation are normal and healthy. They are taught that the important thing is not to remain chaste but to practice safer sex and avoid sexually transmitted infections and pregnancy.

The commitment to "tolerance" so often professed today can further compromise efforts to raise Christian children who appreciate, respect, and express openly their Christian commitments. The Christian understanding that marriage involves one man and one woman united by God forever is scandalous in contemporary secular society. In many countries not only may men marry men and women marry women before the law, but everyone is obligated to recognize such marriages as valid. Even to suggest that such marriages are illicit is considered so politically incorrect as to be hateful. Teaching children about the Christian understanding of marriage while ensuring that they understand how to comport themselves in a secular society is challenging. There is pressure to teach children to be "tolerant" meaning that parents often must qualify Christian teachings with warnings to be careful about what they say and to whom they say it for fear they could have accused of engaging in hate speech.

\section{A. The Houston Equal Rights Ordinance}

These concerns are part of a more general concern that speaking openly against homosexual marriage may be considered hate speech or subject to other restrictions. For instance, in Houston, Texas in May of 2014, the mayor signed the Houston Equal Rights Ordinance (HERO). It banned the same forms of discrimination federal law in the United States already banned, including race, color, ethnicity, national origin, age, religion, disability, pregnancy, 
genetic information, and family, marital or military status. It added sexual orientation and gender identity to the list, and it applied to all businesses serving the public, private employers, housing, city employment and city contracting. Such a ban would mean, among other things, that people could use whatever restroom or locker room matched the gender they chose to identify with. For example, a man who identifies as a woman could use the women's restroom or locker room. Similarly, a teenage girl who identifies as a boy could enter a men's restroom or locker room. It also meant that a business that hosted wedding receptions could not refuse to host a party for a homosexual marriage. Many people were opposed to this ordinance. Several groups began collecting signatures to demand a referendum to vote on whether to keep or to repeal the ordinance. If they collected 7,269-valid signatures, the city would have to hold a vote that would allow the people of Houston to decide whether to keep the ordinance or repeal it. Many churches opposed the ordinance and wanted to see it repealed. Some pastors talked about the referendum in their churches, often because they opposed homosexual marriage. The city received more than 50,000 signatures asking for a vote on the ordinance. The mayor's office, which supported the ordinance, announced that many of the signatures were not valid and no referendum would be held. The groups involved believed the signatures were valid and the city government was simply trying to prevent the referendum from taking place. Some of the groups sued the city government. The city government responded by issueing subpoenas demanding copies of sermons that had been delivered at area churches. The subpoenas demanded copies of "all speeches, presentations, or sermons related to HERO, the Petition, Mayor Annise Parker, homosexuality, or gender identity prepared by, delivered by, revised by, or approved by you or in your possession". Many people saw this as an inappropriate use of government power and believed the city was trying to intimidate churches and religious leaders to prevent them from speaking out against the ordinance and homosexual marriage. They city eventually said that they wanted to 
look at the speeches to see whether any of the pastors had given instructions for collecting signatures since there was an ongoing lawsuit about whether the signatures were valid. But the subpoenas demanded much more than information about instructions that might have been given regarding signing the petition. They demanded all material in any way related to the matter, and as such many people reasonably worried that they were going to be accused of hate speech for speaking out against homosexual activities and the view that people may choose their gender identities (Driessen 2014a and b; Gershman 2014; Morris 2014a and b; Starnes 2014; Volokh 2014; Zavadski 2014). When the ordinance was put to a vote, it failed (Driessen 2015).

\section{B. The United Nations Convention on the Rights of the Child}

These concerns about public pressures that conflict with Christian commitments are not local to the USA. There are international documents that could be seen as restricting the authority of parents to limit the exposure of their Christian children to nonChristian views of the world and ways of life. In this regard, the United Nations Convention on the Rights of the Child (1989) is notable. Romania signed and ratified the Convention in 1990 along with many other countries. The United States as not ratified the Convention. If one takes the Convention seriously, parents would have very little authority over what their children read, whether their children participate in any religions activities and if so which ones, and many other things. To take the Convention seriously is to displace the family. Here are examples of articles in the UN Convention on the Rights of the Child that raise concerns about the family and authority of parents to raise their children as they believe is right. 


\section{Article 13}

1. The child shall have the right to freedom of expression; this right shall include freedom to seek, receive and impart information and ideas of all kinds, regardless of frontiers, either orally, in writing or in print, in the form of art, or through any other media of the child's choice.

2. The exercise of this right may be subject to certain restrictions, but these shall only be such as are provided by law and are necessary:

(a) For respect of the rights or reputations of others; or

(b) For the protection of national security or of public order (ordre public), or of public health or morals.

This article makes powerful claims and imposes significant restrictions on anyone who would limit a child's conduct. Is all religious information to be considered biased? Do parents have no right to restrict their children's access to information they deem inappropriate? If the child chooses to receive traditional religious materials but these materials violate "public morals" as outlined in $2 \mathrm{a}$ of the article, will the child be prohibited from reading them? What are "public morals" and what is to be done when "public morals" contradict religious commitments? This final question is especially important today given that what many consider to be "public morals" involve views that are explicitly contrary to Christianity, such as the permissibility of homosexual marriage. In what others have called a secular fundamentalist culture, "public morals" pose serious challenges to Christianity (Engelhardt 2011; Cherry 2011). 


\section{Article 17}

States Parties recognize the important function performed by the mass media and shall ensure that the child has access to information and material from a diversity of national and international sources, especially those aimed at the promotion of his or her social, spiritual and moral well-being and physical and mental health.

To this end, States Parties shall:

(a) Encourage the mass media to disseminate information and material of social and cultural benefit to the child and in accordance with the spirit of article 29;

(b) Encourage international co-operation in the production, exchange and dissemination of such information and material from a diversity of cultural, national and international sources;

(c) Encourage the production and dissemination of children's books;

(d) Encourage the mass media to have particular regard to the linguistic needs of the child who belongs to a minority group or who is indigenous;

(e) Encourage the development of appropriate guidelines for the protection of the child from information and material injurious to his or her well-being, bearing in mind the provisions of articles 13 and 18.

Consider the information available to children today via mass media. Do parents lack the authority to prevent their children from 
accessing this information? Do children have a right to access this information? Part of what we see here and in many other articles is the assumption that the UN or some state entity is equipped to know what is in a child's interest, and what will contribute to or detract from a child's well-being. State parties must assess what is in a child's social, spiritual and moral well-being and physical and mental health and, using that information, ensure that a child has access to relevant materials. What would it mean for a state to make all of those judgments? What does that mean for the role of parents?

It is in a world hostile to the authority of parents that Christian parents must raise their children today. To counteract these pressures alone is quite difficult for parents because they come from many different directions. The Church can help parents to withstand these pressures.

\section{Health Care}

While the UN Convention introduces threats to parental authority and the integrity of the family across many domains, additional threats with respect to health care emerge in the United States and in any other country that seeks to give children and adolescents greater authority over health care decisions. Ordinarily, parents have been recognized as being in authority to make medical decisions for their children (Iltis 2013). Different jurisdictions recognize people as adults at different times, but a common age of majority is 18 . Up until that point, parents typically have authority over their children and most medical interventions require parental permission. It would not be in children's interest, for instance, to require parental permission for life-saving emergency medical treatment. There also are rare cases in which parents are not appropriate decision makers, as might be the case when a child requires medical treatment as a result of parental abuse. These first two exceptions to requiring parental permission make sense to many people. A third set of exceptions are more controversial. These are 
exceptions for areas where requiring parental permission might pose a barrier to receiving health care. For example, if teens need parental permission to obtain birth control pills, they might not get access to contraception. Other types of health care considered "sensitive" and that some people have said should be part of this special sphere of health care that does not require parental permission include mental health counseling, treatment for drug addiction, and treatment for sexually transmitted infections. In the United States, all states recognize some special areas where what are called "mature minors" may consent to medical treatment without parental knowledge or permission (Ewald 1981; Oberman 1996; Dickens and Cook 2005; Ford et al 2004). Many people have defended the importance of this special sphere, which in some states includes abortion, as essential for protecting and promoting the health of children.

The notion of the mature minor, someone who has not reached the age of majority but has the capacity to make his own health care decisions, has been used to support claims that that socalled mature minors should have even more authority over their health care decisions in general and not just in the special spheres (Hyun 2000; Bluestein and Moreno 1999; Bluestein and Levine 1999). A number of studies have suggested that many adolescents have the cognitive ability to make decisions comparable to the way many adults do (Weithorn and Campbell 1982; Grisso and Vierling 1978). These have been used to defend the mature minor doctrine, which further limits the authority of parents and could allow children to make health care decisions that violate their faith. Despite arguments defending the authority of adolescents based on their cognitive abilities, more recent research calls these claims about their decision-making ability into question (Steinberg 2013; Partridge 2010; Partridge 2013). Regardless of the evidence, there are social pressures to maintain and expand the authority of adolescents over their health care. The desire to support so-called reproductive rights, to treat sexual experimentation and fornication as "normal" requires this protected sphere. 
The extensive pressures Christians face and that challenge the authority of parents and the integrity of the family are a second reason the Church has an important role to play in helping parents in their effort to raise Christian children.

\section{Parenting Without an Example}

The third reason for the Church to support parents in their efforts to raise Christian children is that the parents themselves might not have been raised in pious Orthodox Christian households. Even in countries in which many Christians were baptized as infants and are "cradle Orthodox", they might not have been raised by parents who practiced the Faith. Although they have been Orthodox their whole lives, such parents do not have good examples from their own homes of how to raise children in the Faith. How does one teach children to live and defend the Faith in the face of external pressures? For instance, how may parents help their children to respond when others attack them and accuse them of worshiping idols because of our use of icons? What are the best ways to help teenagers understand the importance of fasting in a world always focused on instant gratification? Teenagers in particular may ask questions that merit correct and thoughtful responses. Why may only men be priests? Why is abortion legal? Why is abortion wrong? Why does the Church teach that marriage only may take place between one man and one woman? Why does our wedding ceremony still say that the man is the head of the household? What does the Church teach about suicide? Is it wrong to get a tattoo? Is it really wrong to have sex if you are engaged to be married? Did Jesus really rice from the dead? There are many other questions teens might ask. Parents who themselves are not educated in the Faith might find themselves unable to answer them. Parents need to be able to continue to learn about the faith so that they can share it with their children. Helping parents understand the Faith so that they can share it with their children is important. Learning the Faith alone will not suffice; parents may need help in learning how to share it with their children 
and how to help their children stand against secular forces that would pull them away.

Adults not raised in pious Orthodox Christian homes may be unfamiliar with many traditions and practices that are important in the Church. Thus they may be unable to pass these on to their children. Traditions that are not shared die. Many of these small traditions are important for supporting the Faith. For instance, do children know how properly to venerate icons upon entering and leaving a church? Do they know that parishioners typically bake the prosphora and have they seen that done? Do children know when to cross themselves in church and when to bow to receive a blessing? Do they know how to greet a priest? Do they know why we celebrate memorials? Have they been involved in preparing for a memorial? Parishes can play an important role in sharing these traditions with those who were not raised with them. Parishioners and priests should not assume that everyone in the community had a mother or grandmother who taught them these things.

For all of these reasons, many parents need help to raise their children in the Church. This can come in the form of adult education and other forms of support for adults as well as programs that support children in their Christian development. Specific examples are discussed below.

\section{Conclusions}

Even though parents bear the primary responsibility for bringing up their children in the faith, the Church has a vital role to play in supporting and supplementing parents' efforts to raise pious Orthodox Christian children for the reasons outlined here. Here I offer a few examples of some ways in which the Church might support parents in this effort, which can be a great struggle in the $21^{\text {st }}$ century.

The first is to help parents, and adults in general, be educated in the Faith. Opportunities for adult education, including but not 
limited to catechism classes, are important. Adult education can include discussion of practical considerations in raising children as well as education in the Faith itself.

The second is to help children learn the Faith through Church School programs and children's ministries. For example, our parish has an active Church School program; classes meet an hour before liturgy. Each year we have a theme and provide teachers with curriculum materials to teach various age groups. Our theme this year is the Creed. We have been going through the Creed phrase by phrase to help children learn what the Creed means. We have used this as an opportunity to teach about the ecumenical councils and some Church history as well. Next year's theme will be the liturgy. We will go through each part of the liturgy so that the children know what is happening, when and why.

The third is to provide young people an opportunity to build social relationships with Orthodox Christian peers. In addition to having a Church School program for our children and teens, our parish have developed a youth (teen) group called Orthodox Church in America Teens. The group meets twice per month. One event is a social activity and the other is a discussion with our parish priest and his wife on a topic important to teens. For example, they have talked about fighting temptation, how to handle conversations about homosexuality with peers, how to prepare for confession, and other difficult topics. These conversations help them to trust the priest and his wife, help them to learn about their Faith in the context of realworld struggles teens face. These interactions also further support their friendship with other Orthodox teens. The youth group also does other activities from time to time. They have learned to read the psalter over the tomb all night on Great and Holy Friday. They stay in the church (with several adults) and take turns reading the Psalms. Every summer, we take a group of girls to a women's monastery for several days. They volunteer in the community and in the parish occasionally as well. The goal is to help them learn more 
about the Faith and how to live it as well as to build an Orthodox peer group. This peer group, we believe, is very important.

These are examples of activities that can help support the ministry of the Church to children and families. This is not to say that these same practices will work in every community. They are meant only as examples. But they do give a sense of the kinds of things that can be important to parents raising children, particularly teenagers, in the Church. Parents cannot provide these opportunities and experiences alone. Ministering to children and parents is an important task of the parish.

In a world in which time and financial resources are limited, it may be tempting to limit ministry to children and families as outlined here. Parishes should resist this temptation. Social circumstances today make it extraordinarily difficult for parents to bring their children up in the Faith alone. The social and political pressures against the Christian life are immense. 


\section{References}

1. Blustein, Jeffrey, and Carol Levine, The adolescent alone: decision making in health care in the United States. Cambridge University Press, 1999.

2. Blustein, Jeffrey, and Jonathan D. Moreno, Valid consent to treatment and the unsupervised adolescent, in: "The adolescent alone: decision making in health care in the United States", Cambridge University Press, Cambridge/New York (1999): 100-110.

3. Cherry, Mark J. Sex, abortion, and infanticide: The gulf between the secular and the divine, in: "Christian Bioethics" 17.1 (2011): 25-46.

4. Coleman, James S. The adolescent society, Oxford: Free Press of Glencoe (1961).

5. Dickens, B. M., and Rebecca J. Cook, Adolescents and consent to treatment, in: "International journal of gynecology \& obstetrics" 89.2 (2005): 179-184.

6. Driessen, Katherine, City Subpoenas Sermons in Equal Rights Case, in: "Houston Chronicle", 14 October 2014a.

7. Driessen, Katherine, Amid Blowback, City Walks Fine Line on Pastor Subpoenas, in: "Houston Chronicle", 16 October 2014b.

8. Driessen, Katherine, Houston Equal Rights Ordinance Fails by Large Margin, in: "Houston Chronicle", 4 November 2015.

9. Duncan, Otis Dudley, Archibald O. Haller, and Alejandro Portes, Peer influences on aspirations: A reinterpretation, in: "American Journal of Sociology" (1968): 119-137.

10. Engelhardt, H. Tristram, Christian bioethics after Christendom: Living in a secular fundamentalist polity and culture, in: "Christian Bioethics" (2011): cbr004.

11. Ewald, Linda Sorenson, Medical decision making for children: an analysis of competing interests, in: "Louis ULJ", 25 (1981): 689.

12. Ford, Carol, Abigail English, and Garry Sigman, Confidential health care for adolescents: position paper of the Society for Adolescent Medicine, in: "Journal of Adolescent Health" 35.2 (2004): 160-167.

13. Gershman, Jacob, Houston Mayor Says City's Sermon Subpoenas Came as a Surprise, in: "The Wall Street Journal", 15 October 2014.

14. Grisso, Thomas, and Linda Vierling, Minors' consent to treatment: A developmental perspective, in: "Professional Psychology" 9.3 (1978): 412.

15. Hyun, Insoo, When adolescents 'mismanage' their chronic medical conditions: An ethical exploration, in: "Kennedy Institute of Ethics Journal" 10.2 (2000): 147-163. 
16. Iltis, Ana S., Parents, adolescents, and consent for research participation, in: "Journal of Medicine and Philosophy" (2013): jht012.

17. Kandel, Denise B., and Kenneth Andrews, Processes of adolescent socialization by parents and peers, in: "International Journal of the Addictions" 22.4 (1987): 319-342.

18. Lashbrook, Jeffrey T., Fitting in: Exploring the emotional dimension of adolescent peer pressure, in: "Adolescence" 35.140 (2000): 747.

19. Morris, Mike, Council Passes Equal Rights Ordinance, in: "Houston Chronicle", 29 May 2014a.

20. Morris, Mike, Equal Rights Ordinance on Hold Pending Hearing, in: "Houston Chronicle", 7 August 2014b.

21. Nelson, R. Michael, and Teresa K. DeBacker, Achievement motivation in adolescents: The role of peer climate and best friends, in: "The Journal of Experimental Education" 76.2 (2008): 170-189.

22. Oberman, Michelle, Minor rights and wrongs, in: "JL Med. \& Ethics", 24 (1996): 127.

23. The Orthodox Study Bible, Nashville, TN: Thomas Nelson (2008).

24. Partridge, Brian C., Adolescent psychological development, parenting styles, and pediatric decision making, in: "Journal of Medicine and Philosophy" (2010): jhq044.

25. Partridge, Brian C., The decisional capacity of the adolescent: an introduction to a critical reconsideration of the doctrine of the mature minor, in: "Journal of medicine and philosophy", 38.3 (2013): 249-255.

26. Pomozansky, Fr. Michael. (1991). The Purpose of the Orthodox Parish. Available online: http://www.roca.org/OA/146/146g.htmOinizabsjtm. Originally appeared in Russian in Pravoslavnaya Rus, No. 11, 1955; translated from Blagovestnik, a parish bulletin of the Holy Virgin Cathedral, San Francisco, CA, November 1991.

27. Shah, Farida, and Melvin Zelnik, Parent and peer influence on sexual behavior, contraceptive use, and pregnancy experience of young women, in: "Journal of Marriage and the Family" (1981): 339-348.

28. Starnes, Todd, City of Houston Demands Pastors Turn Over Sermons, in: "FoxNews.com.", 14 October 2014.

29. Steinberg, Laurence, Does recent research on adolescent brain development inform the mature minor doctrine?, in: "Journal of Medicine and Philosophy" (2013): jht017.

30. United Nations. (1989). Convention on the Rights of the Child. Treaty Series, 1577, 3.

31.Volokh, Eugene, Is It Constitutional for a Court to Enforce a Subpoena of Ministers' Sermons?, in: “The Washington Post”, 15 October 2014. 
32. Weithorn, Lois A., and Susan B. Campbell, The competency of children and adolescents to make informed treatment decisions, in: "Child development" (1982): 1589-1598.

33. Zavadski, Katie, Is Houston's Lesbian Mayor Really Out to Get Conservative Preachers?, in: "New York", 15 October 2014. 